\title{
Exploring Motivational Strategies Practiced by Saudi High School Female EFL Teachers
}

\author{
Aisha T. Alharbi ${ }^{1}$ \\ ${ }^{1}$ Researcher of Applied Linguistics, Department of English Language and Translation, College of Arabic \\ Language and Social Studies, Qassim University, Saudi Arabia \\ Correspondence: Aisha Alharbi, Researcher of Applied Linguistics, Department of English Language and \\ Translation, College of Arabic Language and Social Studies, Qassim University, Saudi Arabia
}

Received: April 25, 2020

doi: 10.5539/elt.v13n6p109
Accepted: May 21, 2020

Online Published: May 22, 2020

URL: https://doi.org/10.5539/elt.v13n6p109

\begin{abstract}
This study looked into Saudi female English as a Foreign Language (EFL) teachers' perception of their motivational practices in the actual classroom in public and private schools. Forty $(n=40)$ EFL teachers filled out a questionnaire consisting of forty-four motivational strategies that were based on a five-point Likert scale ranging from "very important" to "not important." Descriptive statistics have been used to determine the most and the least important teaching strategies viewed by EFL teachers in private and public schools. To determine if there was any difference between private and public schools' teachers on how they viewed each strategy in terms of importance, inferential statistics, t-test has been implemented. The study revealed that participants in both educational contexts indicate that "teachers' proper behavior" is the most significant motivational strategy while "having an encouraging environment" in the EFL classroom was ranked the least important strategy. The findings show that there existed a striking similarity between the two sets of teachers in regard to their perceptions of the importance of motivational strategies. The study suggests that English-as-a-Second-Language book planners should keep textbook materials in harmony with motivational strategies practiced by EFL teachers.
\end{abstract}

Keywords: motivational strategies, teacher behavior, motivation, private/ public sector

\section{Introduction}

Motivation is a significant factor that affects second foreign language learning; as such, the role of motivation has been broadly explored in foreign/second language research (e.g., Dörnyei, 1994, 2005, 2010; Dörnyei \& Ottó, 1998; Dörnyei \& Ushioda, 2011; Gardner, 1985). Although the field of second $\backslash$ foreign language learning lacks a consensus of many issues, there is a notable agreement on that motivation is a driving force that inevitably affects the learning status (Alrabai et al., 2013). It has been acknowledged that even the most intelligent learners may not reach their full learning potentials without motivation. According to many L2 researchers, motivated learners are more successful than demotivated ones (Cheng \& Dörnyei, 2007; Guilloteaux \& Dörnyei, 2008; Alrabai et al., 2013).

Given that motivation is a critical factor that determines success in foreign language learning, teachers' practices for motivating EFL students are deemed as an essential aspect of second $\backslash$ foreign language motivation research (Cheng \& Dörnyei, 2007). That is, in the EFL classroom, teachers encounter many difficulties with unmotivated learners. So, in an attempt to motivate those students, teachers use specific strategies to urge those students to be motivated in the actual classroom. Different studies indicated the need for effective teaching strategies, including strategies designed for motivating EFL learners (Dörnyei, 2001; Cheng \& Dörnyei, 2007; Alrabai, 2010). It is believed that learners' motivation is closely related to teachers' practices in the classroom in which teachers' using different strategies may keep students engaged and motivated (Guilloteaux \& Dörnyei, 2008; AlKaboody, 2013; Alizadeh, 2016). In other words, EFL Teachers' application of motivational strategies in the actual classroom is one of the critical factors that determine students' success, or lack therefore, in learning a foreign language.

Dörnyei (2001, p.28) describes motivational strategies as "the motivational influence that are consciously exerted to achieve some systematic and enduring positive effect." According to Guilloteaux and Dörnyei (2008), motivational strategies can be divided into two categories: (1) intentional instructions used by instructors to obtain 
and spur learners' motivation and, (2) self-regulating strategies practiced by students to maintain their motivations' level. The present study is concerned with investigating the former.

\subsection{Context of the Problem}

Different studies have noted that the levels and types of motivation may vary considerably among EFL learners, which, in turn, justify the need for strategies to cater for differences among learners regarding motivation. The studies investigating Saudi students' motivation have focused on identifying the types and levels of Motivation among EFL learners (Al-Shamary, 1984; Al- Otaibi, 2004; AlMaiman, 2005), which results in a shortage of research done on the practical dimension that intended to promote learner motivation in the actual classroom. Therefore, in response to this literature gap and, also, drawing on the fact that teachers' practices have a tremendous impact on students' motivation, this study focused on the motivational practices used by EFL teachers. Although different researchers have investigated Saudi EFL teachers' motivational strategies (Alrabai, 2011; Al Arabia, 2014; Alqahtani, 2016), not much attention has been given on the motivational practices of EFL teachers in two different educational contexts, namely: private schools and public schools. In view of this, this study explored Saudi EFL female teachers' beliefs about the importance of the motivational strategies they use in the actual classroom to motivate their students. Also, this study draws a comparison between the perceptions of EFL teachers in public and private schools regarding the importance of motivational strategies.

This study is of significant value because it aims to bring teachers' attention to the importance of the practice of motivational strategies in EFL classrooms and how it affected students' behavior, as Alarabi (2014) has suggested. Consequently, the findings of this study could improve English instruction as they offered teachers insights into motivational strategies that are significant to learning. Similarly, this study's results would point teachers to some of the effective motivational strategies that they could integrate into their teaching curriculum/syllabus to increase learning.

\subsection{Research Questions}

The study sought to answer the following questions:

What is the most important and least important motivational strategy practiced by Saudi female EFL teachers in public and private sectors?

Are there differences between EFL teachers in public and private sectors in regard to their perception of the importance of motivational strategies?

\subsection{Research Objectives}

In this study, the objectives were two-fold:

To examine if there existed any significant difference in the use of motivational strategies between EFL teachers in public and private schools.

To examine how different educational contexts contribute to teachers' perception of the use of motivational strategies.

\section{Review of Literature}

\subsection{Theoretical Background}

\subsubsection{Definition of Motivation}

Csizer (2017) maintains that the history of the study of L2 motivation is as rich as the concept is intricate. Due to its complexity, defining motivation may not be straightforward. Dörnyei and Ushioda (2001) agree, noting that in any attempt to define it, two principal elements must be present: "direction and magnitude" (Dörnyei, 2001, p.8). Motivation can be described as "the choice of a particular action, the persistence with it, and the effort expended on it" (Dörnyei, 2000, p. 520). Similarly, Richards and Schmidt (2013) define motivation as the driving force of our actions. It is believed that motivated L2 learners have reasons to choose something and work hard and long enough to achieve it.

\subsubsection{Theories of L2 Motivation}

Since it might be impossible to give a full description of the theories of L2 Motivation, Dornyei (2005) has provided a brief account of various studies and theories, classifying the development of the field into three phases. The work of Gardner and Lambert (1972), which was based on a social-psychological theory, gave rise to the first phase of the development of L2 motivation studies. The second phase took place in 1990 when motivation studies shifted from social-psychological theories to cognitive theories. The third phase covers the 
period from 2000 to the present. Within this time, L2 motivational research has witnessed a shift from a cognitive-situated view to a process-situated approach.

The first phase was associated with Gardner's remarkable work and the highly prominent integrative-instrumental motivation dichotomy (Dornyei, 2013). According to Gardner and his colleagues (1972), integrative motivations are the "primary force responsible for enhancing or hindering intercultural communication and affiliation." As such, learners' attitude toward learning a second language, including their desire to connect with other cultures, was considered as a prime principle of Gardner and his associates' work. It determines success or failure in learning a second language. Later on, however, studies and theories based on the social-psychological approach were replaced by those which focus more on cognition. As the cognitive approach dominated the field from 1990 to 2000, psychological theories pertaining to "the learner's self" emerged (Dornyei, 2001). From 2000 to the present, L2 motivation research has seen a shift from a cognitive-situated view to a process-situated approach. In this phase, attention has been given to the dynamic aspects of learning a second language.

\subsubsection{Motivational Strategies}

Motivational strategies are viewed as the practical dimension of theories of L2 motivation. They are an essential aspect of research in second language motivation because they link the theoretical dimension to the practical one by transforming motivational theories into practical strategies that can be used in the L2 classroom. Motivational strategies refer to the conscious effort to achieve systemic and permanent results (Dörnyei, 2001). They are techniques teachers use to change students' behavior and attitudes towards learning.

Dörnyei (2001) has outlined a variety of strategies that teachers could use in the L2 classroom. Dörnyei organized these strategies under a systemic theoretical framework called "Motivational Teaching Practice" (p. 29). The model includes primary strategies and sub-strategies that are classified into four categories. The primary dimensions of these categories are: "(1) creating the basic motivational conditions, (2) generating initial motivation, (3) maintaining and protecting motivation, and (4) encouraging positive retrospective self-evaluation" (Dörnyei, 2001, p. 29).

Each of these dimensions includes some micro strategies. The first-dimension entails techniques that aim at creating appropriate conditions in the classroom to keep learners motivated. Teachers can do this by (1) establishing a healthy, positive rapport with students, (2) creating a relaxing environment in class, and (3) promoting cohesiveness among students.

The second dimension focuses on generating students' initial motivation by introducing them to the foreign language's culture and values. Here teachers raise students' interest in knowing more about the second language community. This dimension is also concerned with promoting students' expectancy of success and helping them to have identifiable and attainable goals when learning a foreign language. The third dimension has to do with maintaining students' motivation. This involves creating a refreshing and pleasant classroom experience. The fourth category involves strategies that focus on promoting students' positive self-assessment. Some of these strategies emphasize fostering students' self-satisfaction as well as providing them with positive feedback.

\subsection{Related Studies}

Over the past forty years, most of the studies on L2 motivation have explored different aspects of the subject in relation to what motivation as a theoretical concept means. Thus, they neglected the practical aspect of L2 motivation, which is what happens in classrooms (Al-Alrabai, 2011; Cheng \& Dörnyei, 2007). Accordingly, other studies started to pay more attention to motivational strategies as a significant practical dimension of L2 motivation (e.g., Dörnyei \& Csizeŕ, 1998; Alrabai, 2010; Moskovsky et al., 2013; Al Qahtani, 2016).

Studies had been conducted in various locations to investigate motivational strategies. For example, Dörnyei and Csizeŕ (1998) asked 200 Hungarian EFL teachers to rank fifty motivational strategies in terms of importance and frequency of use. Likewise, Cheng and Dörnyei (2007) conducted a large-scale study in Taiwan. Three hundred eighty-seven Taiwanese EFL teachers were surveyed to determine the number of motivational strategies according to their importance and frequency of use. Drawing a comparison between the two studies' findings, Dörnyei (2007) noted similarities between Hungarian and Taiwanese teachers in their ranking of some of the strategies, although there were some differences. He concluded that while some motivational strategies were dependent on culture, most could be transferred across cultures. Unlike Dörnyei and Csizeŕ (1998) and Cheng and Dörnyei (2007), Guilloteaux and Dörnyei (2008) were concerned with identifying a potential link between teachers' motivational strategies and their students' level of motivation. They used a smaller sample size compared to the two past studies. The participants were twenty-seven South Korean EFL teachers, and more 
than 1,300 EFL learners. To collect data, Guilloteaux and Dörnyei utilized multiple instruments, namely a Self-Reporting Questionnaire and a teacher post-lesson assessment tool. The findings showed that teachers' motivational practices had an impact on students' motivation.

In Saudi Arabia, several studies, although limited, have investigated EFL teachers' motivational strategies (Alrabai, 2010; Moskovsky et al., 2013; Al Qahtani, 2016). Both Alrabai (2010) and Al Qahtani (2016) explored the motivational techniques used by Saudi EFL teachers, with a concentration on perceptions of motivational strategies in terms of importance. Meanwhile, the study by Moskovsky et al. (2013) involved not only Saudi EFL teachers but also EFL learners. The researchers used a pretest-posttest design as well as a quasi-experimental design. Their findings suggested that teachers' use of motivational strategies greatly influence learners' motivation.

All studies mentioned above have explored different motivational strategies that EFL teachers implemented in EFL classes. They were conducted in different contexts (i.e., Hungary, Taiwan, Saudi Arabia, and Korea), and they primarily used survey instruments. However, this study has been conducted in Saudi Arabia, zeroing in on educational contexts, namely public and private instruction.

The literature review has shown that the findings of previous studies may not be adequate for all EFL learning situations. Guilloteaux and Dörnyei (2008) assert that researchers should answer whether the proposed motivational techniques are effective in all classrooms. Dörnyei (2001) maintains that strategies suitable in one context may not be suitable in other contexts. Not much attention has been given as to what motivational techniques Saudi female teachers working in two different educational contexts should adopt. Towards this end, this current study was set to examine the differences, if any, between private- and public-school teachers' motivational practices.

\section{Method}

\subsection{Participants}

The study used a quantitative research design in which forty female EFL teachers had been selected as samples. A survey instrument was administered to the teachers (twenty public school teachers, and twenty private school teachers) who were chosen randomly from forty secondary schools in Buraydah City, Al Qassim region, Saudi Arabia. The number of private school teachers selected was almost representative of the number of private schools in Buraydah City. Teachers of both sectors were native speakers of Arabic and held different qualifications: a BA degree (sixteen public school teachers and nineteen private) and an MA degree (four public school teachers and one private).

\subsection{Instrument}

To obtain data, a questionnaire was used in this study. The first part of the questionnaire sought to gather participants' demographic information such as age, years of experience, and qualification. The second consisted of forty-four strategies: Ten macro-level strategies and thirty-three micro-level strategies. The thirty-three micro-strategies fell under ten categories. Teachers were asked to classify the motivational strategies according to their significance. The items in the questionnaire were obtained from different sources (Dörnyei\&Csizer, 1998; Cheng \&Dörnyei, 2007; Guilloteaux\&Dörnyei, 2008). The questionnaire was based on a five-point Likert, ranging from "very important" to "not important." The Cronbach's alpha was acceptable at $[\alpha=0.74]$ for all dimensions. The credibility achieved a good result of over 0.80 . Thus, the scales were valid and reliable for fulfilling the research objectives.

This research was conducted during the second semester of the academic year 2020. A Google form application was used to create electronic questionnaires, which were sent to the participating teachers via email. To reduce misunderstanding and to address ethical concerns, the questionnaires were accompanied by all necessary information and instructions.

\section{Data Collection and Analysis}

To find answers to the research questions, the author used descriptive and inferential statistics. With regard to the first question, means and standard deviations were calculated using the statistical program SPSS. To determine the difference between public and private EFL teachers' implementation of motivational strategies, the author performed an Independent Samples t-test in SPSS.

\section{Findings}

As shown in Table 1 below, EFL teachers in both sectors perceive the use of proper teacher behavior $(\mathrm{M}=4.62$, $\mathrm{SD}=0.44)$ as the most important motivational strategy followed by promoting students' self-confidence $(\mathrm{M}=4.21$, 
$\mathrm{SD}=0.57)$. On the other hand, creating a pleasant classroom atmosphere $(\mathrm{M}=3.75, \mathrm{SD}=0.83)$ appeared to be less important.

Table 1. Findings on the motivational strategies employed by EFL teacher

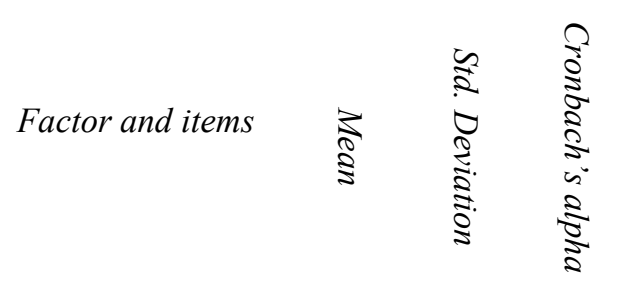
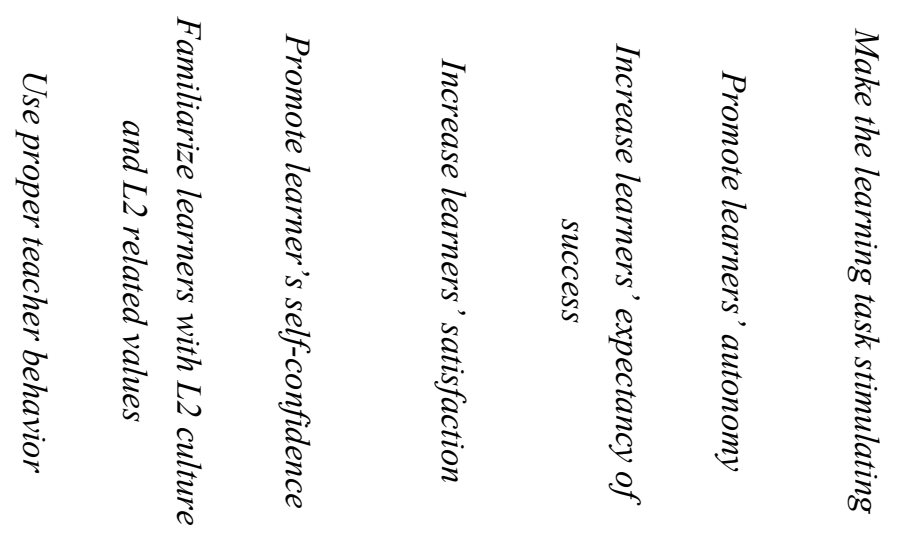

\begin{tabular}{|c|c|c|c|c|c|c|c|c|c|c|c|c|c|}
\hline $\begin{array}{c}\text { Proper teacher } \\
\text { behavior }\end{array}$ & 4.62 & 0.44 & 0.72 & 1 & & & & & & & & & \\
\hline Familiarize learners & & & 0.82 & & & & & & & & & & \\
\hline $\begin{array}{l}\text { with L2 culture and } \\
\text { L2 related values }\end{array}$ & 4.20 & 0.68 & & 0.17 & 1 & & & & & & & & \\
\hline $\begin{array}{c}\text { Promote learners' } \\
\text { self-confidence }\end{array}$ & 4.21 & 0.57 & 0.75 & $0.49^{* *}$ & $.53^{* *}$ & 1 & & & & & & & \\
\hline $\begin{array}{c}\text { Increase learners' } \\
\text { satisfaction }\end{array}$ & 4.09 & 0.72 & 0.73 & 0.17 & 0.15 & $0.45^{* *}$ & 1 & & & & & & \\
\hline Increase learners' & & & 0.78 & & & & & & & & & & \\
\hline $\begin{array}{l}\text { expectancy of } \\
\text { success }\end{array}$ & 4.15 & 0.54 & & $0.50 * *$ & $0.61^{* *}$ & $0.67 * *$ & $0.52^{* *}$ & 1 & & & & & \\
\hline $\begin{array}{c}\text { Promote learners' } \\
\text { autonomy }\end{array}$ & 4.12 & 0.59 & 0.80 & 0.04 & $0.58^{* *}$ & $0.56^{* *}$ & 0.209 & $0.50 * *$ & 1 & & & & \\
\hline $\begin{array}{l}\text { Make the learning } \\
\text { task stimulating }\end{array}$ & 3.94 & 0.77 & 0.81 & $0.46^{* *}$ & $0.62^{* *}$ & $0.42^{* *}$ & $0.36^{*}$ & $0.63 * *$ & $0.59 * *$ & 1 & & & \\
\hline Create a pleasant & & & 0.75 & & & & & & & & & & \\
\hline $\begin{array}{l}\text { classroom } \\
\text { atmosphere }\end{array}$ & 3.75 & 0.83 & & 0.09 & $0.53^{* *}$ & $0.46^{* *}$ & 0.181 & $0.43^{* *}$ & $0.58^{* *}$ & $0.46^{* *}$ & 1 & & \\
\hline Increase learners' & & & 0.77 & & & & & & & & & & \\
\hline $\begin{array}{l}\text { positive goals and } \\
\text { realistic beliefs }\end{array}$ & 4.10 & 0.71 & & 0.21 & $0.61^{* *}$ & $0.602 * *$ & 0.280 & $0.65^{* *}$ & $0.62 * *$ & $0.69 * *$ & $0.47 * *$ & 1 & \\
\hline Promote group & & & 0.89 & & & & & & & & & & \\
\hline $\begin{array}{l}\text { cohesiveness and } \\
\text { set group norms. }\end{array}$ & 4.01 & 0.61 & & $0.57 * *$ & $0.69^{* *}$ & $0.659^{* *}$ & $0.426^{* *}$ & $0.64^{* *}$ & $0.67 * *$ & $0.64 * *$ & $0.61^{* *}$ & $0.75^{* *}$ & 1 \\
\hline
\end{tabular}

\section{** Correlation is significant at the 0.05 level (2-tailed).}

Overall, the motivational techniques implemented by EFL teachers in public schools ranged from $[M=4.60$, $\mathrm{SD}=0.50]$ to $[\mathrm{M}=3.94, \mathrm{SD}=0.92]$, which means that all constructs were important to $\mathrm{EFL}$ teachers in public schools. The motivational strategies employed by $E F L$ teachers in private schools ranged from $[M=4.63, \mathrm{SD}=0$. 39] to $[\mathrm{M}=3$. $55, \mathrm{SD}=0.69]$, which also means that all constructs were important to EFL teachers in private 
schools. Moreover, as shown in Table 1, most correlations were statistically and positively achieved; they ranged from $[\mathrm{r}=0.43, \mathrm{p}<0.05)]$ to $[\mathrm{r}=0.69, \mathrm{p}<0.05]$. These results proved that the constructs were related.

To address the second research question, an Independent Sample t-test was performed. As shown in Table 2, there were no significant differences in mean scores for all constructs of private and public sectors $(\mathrm{p}>0.05)$, except for familiarizing learners with L2 culture and L2-related values construct, which took precedence among public school teachers. The mean difference was $0.45(\mathrm{t}=2.24, \mathrm{p}<0.05)$. Hence, the author found that EFL teachers in public and private schools ranked the motivational strategies in almost the same way.

Table 1. T-test between public and private schools $(\mathrm{N}=40)$

\begin{tabular}{|c|c|c|c|c|c|c|c|c|}
\hline Factor & Sector & Mean & Degree & $S D$ & $t$ & $d f$ & $\begin{array}{c}\text { Mean } \\
\text { difference }\end{array}$ & $p$ \\
\hline \multirow{2}{*}{ Use proper teacher behavior } & Public & 4.60 & $\begin{array}{c}\text { Very } \\
\text { important }\end{array}$ & 0.50 & -0.21 & 39 & -0.03 & 0.83 \\
\hline & Private & 4.63 & $\begin{array}{c}\text { Very } \\
\text { important }\end{array}$ & 0.39 & & & & \\
\hline \multirow{2}{*}{$\begin{array}{l}\text { Familiarize learners with L2 } \\
\text { culture and L2 related values }\end{array}$} & Public & 4.42 & $\begin{array}{c}\text { Very } \\
\text { important }\end{array}$ & 0.58 & $2.24 * *$ & 39 & 0.45 & 0.03 \\
\hline & Private & 3.97 & Important & 0.72 & & & & \\
\hline \multirow{2}{*}{$\begin{array}{c}\text { Promote learners' } \\
\text { self-confidence }\end{array}$} & Public & 4.16 & Important & 0.56 & -0.62 & 38 & -0.11 & 0.54 \\
\hline & Private & 4.27 & Important & 0.59 & & & & \\
\hline \multirow{2}{*}{ Increase learners' satisfaction } & Public & 4.16 & Important & 0.66 & 0.62 & 39 & 0.14 & 0.54 \\
\hline & Private & 4.02 & Important & 0.79 & & & & \\
\hline \multirow{2}{*}{$\begin{array}{c}\text { Increase learners' expectancy } \\
\text { of success }\end{array}$} & Public & 4.26 & Important & 0.54 & 1.34 & 39 & 0.22 & 0.19 \\
\hline & Private & 4.04 & Important & 0.53 & & & & \\
\hline \multirow{2}{*}{ Promote learners' autonomy } & Public & 4.10 & Important & 0.66 & -0.29 & 39 & -0.05 & 0.77 \\
\hline & Private & 4.15 & Important & 0.52 & & & & \\
\hline \multirow{2}{*}{$\begin{array}{l}\text { Make the learning task } \\
\text { stimulating }\end{array}$} & Public & 4.10 & Important & 0.75 & 1.31 & 38 & 0.32 & 0.20 \\
\hline & Private & 3.78 & Important & 0.78 & & & & \\
\hline \multirow{2}{*}{$\begin{array}{c}\text { Create a pleasant classroom } \\
\text { atmosphere }\end{array}$} & Public & 3.94 & Important & 0.92 & 1.54 & 39 & 0.39 & 0.13 \\
\hline & Private & 3.55 & Important & 0.69 & & & & \\
\hline \multirow{2}{*}{$\begin{array}{l}\text { Increase learners' positive } \\
\text { goals and realistic beliefs } \\
\text { needs }\end{array}$} & Public & 4.17 & \multirow{2}{*}{$\begin{array}{l}\text { Important } \\
\text { Important }\end{array}$} & 0.79 & 0.64 & 39 & 0.14 & 0.53 \\
\hline & Private & 4.03 & & 0.62 & 0.07 & קנה & 0.17 & 0.03 \\
\hline \multirow{2}{*}{$\begin{array}{l}\text { Promote group cohesiveness } \\
\text { and set group norms }\end{array}$} & Public & 4.06 & Important & 0.61 & 0.51 & 39 & 0.10 & 0.62 \\
\hline & Private & 3.96 & Important & 0.62 & & & & \\
\hline
\end{tabular}

**T is significant at the 0.05 level (2-tailed).

\section{Discussion}

\subsection{The Ranking of Motivational Strategies}

Teachers' appropriate behavior came on top of the list, which meant that teachers in both sectors prioritize this strategy in their EFL teaching. Participating teachers perceived teachers' care and acceptance of learners' level of improvement as the most significant micro-strategy under this cluster. Teven (2007) warns that neglecting students and their interests in learning might result in demotivation and, consequently, negative teacher evaluations. Hence, students have to be valued, respected, and allowed to express themselves in a safe environment. Hence, students are more likely to improve if teachers make them feel worthy and show interest in their well-being (Burden, 2000). Thus, it comes as no surprise that displaying appropriate behavior came out in this study as the most important teaching strategy. 
Although it is ignored and downplayed in the EFL classroom (Dörnyei, 2001), the motivational strategy of promoting students' self-confidence ranked as the second most important strategy practiced by teachers in both sectors. Self-confidence and the students' perception of themselves and their abilities to learn are well-explored subjects in the literature (Alrabai, 2017). Students are more likely to be motivated to take risks and overcome obstacles when teachers show confidence in their abilities. Alrabai (2017) says teachers can build students' confidence by assigning them the responsibility to do a task. By doing so, teachers send a signal to their students that they are up to the task. In high school, students typically have more worries and doubts about themselves than they do have self-confidence and pride (Dörnyeis, 2001). Thus, in teaching teenagers, teachers should consider the issue of self-confidence because students are sensitive to their self-image and often do not want to be judged as less than perfect.

In the third rank was the strategy of familiarizing learners with L2 culture and L2-related values. Descriptive statistics showed a difference in the application of this strategy between EFL teachers in public and private schools. While public school teachers ranked this strategy as the second most important macro strategy, it was ranked seventh by private school teachers. This low ranking given by private school teachers may have something to do with the concept of integrativeness since students had little to no contact with the target community.

Learners' expectancy of success as a motivational strategy ranked fourth. EFL teachers working in public and private sectors believed that motivated students had a higher expectancy of success. The participating teachers reported different micro-strategies that they use to foster this strategy, increase learners' expectancy of success. For instance, provide learners with clear instructions and explain the lessons so that they can digest information easily. Also, students are given clear instructions regarding the course and lessons' objectives. Moreover, students are encouraged to prepare at home before the actual class takes place, as this might contribute to heighten students' expectations of themselves.

The fifth-ranking strategy was supporting learners to take control of their learning, which is termed in literature as "learner autonomy." The teachers taught a large number of students, which could be the reason for the relatively low ranking of this strategy. Also, it required students to read the learning material before going to class. The lack of the implementation of this strategy might explain why Saudi students have a low level of motivation. Most of the EFL classes were teacher-centered, in which learners only served as passive recipients of the information. This indicates that autonomous behavior was not encouraged in EFL classrooms in Saudi Arabia.

Although the following motivational strategies did not top the list, they were viewed as important to very important by EFL teachers in both sectors. Teachers believed that students who were guided by realistic goals and the right mindset were motivated to learn the second language. Moreover, increasing learners' satisfaction and promoting group cohesiveness were ranked as the seventh and eighth macro strategies in the EFL classroom, respectively. Promoting group cohesiveness has to do with establishing rapport among learners and fostering group-work and cooperation. According to Alrabai (2010), this low ranking of the strategy of group cohesiveness might be attributed to the large classroom size in Saudi Arabia, which makes the application of this strategy virtually impossible.

Task stimulation and creating a positive learning environment ranked ninth and tenth, respectively. Providing learning activities that are stimulating and engaging fosters a creative atmosphere in classrooms, for it encourages students to take an interest in the subject. However, putting these two strategies into practice might be difficult, as teachers have to cover the whole textbook in one semester. Thus, time constraints discourage teachers from providing stimulating tasks that lead to a creative environment.

\subsection{The Difference between Private and Public-Schools Teachers in the Implementation of Motivational Strategies}

Teachers in both sectors perceive motivational strategies to be an integral part of classroom decorum. Statistics showed that there existed no difference between public and private EFL teachers regarding their perception of their motivational strategies. Thus, we can say that public and private school teachers are fully aware of the importance of motivational practices in EFL teaching. The different educational context was expected to influence the teacher's behavior. For example, teachers in private sectors might not use motivational strategies due to lack of funding, or they might end up shelling out money from their pockets to move the learning process. In this study, however, Saudi EFL teachers in private schools shared the views of their public counterparts on the significance of motivational strategies. This finding might indicate that the private education sector in Saudi Arabia has been transformed by Saudi Arabia's 2030 vision initiatives, where the private sector, along with the 
public, is given financial support. With an education in the kingdom being given importance, Saudi Arabia's 2030 vision guarantees a high quality of education, either private or public.

\section{Conclusion and Recommendations}

The findings from this study showed that participant teachers in both educational contexts (i.e., public and private) were fully aware of their critical role in motivating students. Participating teachers in both sectors perceived motivational strategies as being important or very important. The top practiced strategies include (1) displaying good behavior in the classroom like being a role model, (2) fostering students' sense of confidence, (3) helping students to have a higher expectation of success in learning, (4) and making students take control and responsibility for their learning. Although the other motivational strategies were still perceived as important, they had lower rankings. Challenges faced by EFL teachers can explain strategies that received lower ranking such as having to deal with a big classroom size, time constraints, or a long textbook content.

Moreover, the study found that teachers in public and private schools shared similarities in their perceptions of each strategy's significance; this might be explained by the fact that both sectors were supported by the ministry of education to ensure a high quality of teaching in Saudi Arabia. This study suggests that EFL curriculum designers should incorporate motivational strategies into the program. It is also encouraged that EFL teachers promote anonymity in the classroom. Also, teachers should not confine their lessons to the assigned textbooks but should go beyond them to include as many motivational strategies as they can. It should be noted that this study focused entirely on the importance of using motivational strategies and left out other significant aspects of the matter, such as the frequency of use of these strategies. Future studies can use qualitative methods to collect and observe how teachers in both sectors differ in using and perceiving each strategy's importance.

\section{References}

AL-Qahtani, S. M. A. (2016). Motivational strategies and EFL teachers' perceptions: A Saudi survey. Theory and Practice in Language Studies, 6(4), 663-674. http://dx.doi.org/10.5539/ijel.v7n2p117.

Al-Otaibi, G. N. (2004). Language learning technique use among Saudi EFL students and its relationship to language proficiency level, gender and motivation. (Unpublished $\mathrm{PhD}$ thesis), Indiana University of Pennsylvania.

Al-Shammary, E. (1984). A study of motivation in the learning of English as a foreign language in intermediate and secondary schools in Saudi Arabia. (Unpublished PhD thesis), Indiana University.

AlMaiman, I. (2005). A study of seventh-grade Saudi students' motivation level to learn English as a foreign language. (Unpublished $\mathrm{PhD}$ thesis), University of Kansas.

Alrabai, F. (2007). The role of intrinsic motivation in learning English as a foreign language by Saudi EFL learners. (Unpublished Master thesis), University of Newcastle.

Alrabai, F. (2014). Motivational practices in English as a foreign language classes in Saudi Arabia: Teachers beliefs and learners' perceptions. Arab World English Journal, 5(1), 224-246.

Alrabai, F. (2016). The effects of teachers' in-class motivational intervention on learners' EFL achievement. Applied linguistics, 37(3), 307-333. http://doi.org/10.1093/applin/amu021.

Alrabai, F. (2017). Exploring the Unknown: The Autonomy of Saudi EFL Learners. English Language Teaching, 10(5), 222-233. http://doi.org/10.5539/elt.v10n5p222.

Alrabai, F. A. (2010). The use of motivational strategies in the Saudi EFL classroom. (Unpublished PhD thesis). University of Newcastle, Australia.

Alrabai, F. A. (2011). Motivational instruction in practice: Do EFL instructors at King Khalid University motivate their students to learn English as a foreign language. Arab World English Journal, 2(4), 257-285.

Alizadeh, M. (2016). The impact of motivation on English language learning. International Journal of Research in English Education, 1(1), 11-15.

Burden, P. R. (2000). Powerful classroom management strategies: Motivating students to learn. Corwin Press, Inc.

Cheng, H. F., \& Dörnyei, Z. (2007). The use of motivational strategies in language instruction: The case of EFL teaching in Taiwan. International Journal of Innovation in Language Learning and Teaching, 1(1), 153-174. http://doi.org/10.2167/illt048.0. 
Csizér, K. (2017). Motivation in the L2 classroom. In S. Loewen \& M. Sato (Eds.). The Routledge handbook of instructed second language acquisition, (pp.418-432) New York, NY: Routledge.

Csizér, K., \& Dörnyei, Z. (2005). The internal structure of language learning motivation and its relationship with language choice and learning effort. The Modern Language Journal, 89(1), 19-36. http://doi.org/10.1111/j.0026-7902.2005.00263. x.

Dörnyei, Z. (1994). Motivation and Motivating in the Foreign Language Classroom. Modern Language Journal, 78(1), 273-284. https://doi.org/10.2307/330107.

Dornyei, Z. (1998). Motivation in Second and Foreign Language Learning. Language Teaching, 31(1), 117-135. https://doi.org/10.1017/S026144480001315X.

Dörnyei, Z. (2001). New themes and approaches in second language motivation research. Annual review of applied linguistics, 21(1), 43-59.

Dornyei, Z. (2005). The Psychology of the Language Learner: Individual Differences in Second Language Acquisition. Mahwah, NJ: Lawrence Erlbaum.

Dörnyei, Z., \& Csizér, K. (1998). Ten commandments for motivating language learners: Results of an empirical study. Language teaching research, 2(3), 203-229. https://doi.org/10.1177/136216889800200303.

Dörnyei, Z., \& Otto, I. (1998). Motivation in action: A process model of L2 motivation. Working Papers in Applied Linguistics, 4(1), 43-69.

Dörnyei, Z., \& Ushioda, E. (2013). Teaching and Researching: Motivation. New York: Routledge.

Dörnyei, Z., \& Ushioda, E. (Eds.). (2009). Motivation, language identity and the L2 self. Multilingual Matters.

Ellis, R. (1994). The study of second language acquisition. Oxford: Oxford University Press.

Gardner, R. (1985). Social psychology and second language learning: The role of attitudes and motivation. Edward Arnold.

Gardner, R., \& Lambert, W. E. (1972). Attitudes and motivation in second language learning. Newbury House Publishers.

Guilloteaux, M. J., \& Dörnyei, Z. (2008). Motivating language learners: A classroom-oriented investigation of the effects of motivational strategies on student motivation. TESOL quarterly, 42(1), 55-77. https://doi.org/10.1002/j.1545-7249.2008.tb00207.x

Moskovsky, C., Alrabai, F., Paolini, S., \& Ratcheva, S. (2013). The effects of teachers' motivational strategies on learners' Motivation: A controlled investigation of second language acquisition. Language Learning, 63(1), 34-62. https://doi.org/10.1111/j.1467-9922.2012.00717.x

Teven, J. J. (2007). Teacher caring and classroom behaviour: Relationships with student affect and perceptions of teacher competence and trustworthiness. Communication Quarterly, 55(4), 433-450. https://doi.org/10.1080/01463370701658077

\section{Copyrights}

Copyright for this article is retained by the author(s), with first publication rights granted to the journal.

This is an open-access article distributed under the terms and conditions of the Creative Commons Attribution license (http://creativecommons.org/licenses/by/4.0/). 